\title{
Ocean-atmosphere redox conditions recorded by the 1.88 Ga Sokoman IF
}

GABRIEL P. SINDOL ${ }^{1 *}$, MiCHAEL G. BABECHUK ${ }^{1}$, JAMES CONLIFFE $^{2}$, CAROLINA ROSCA $^{3}$, RONNY SCHOENBERG ${ }^{3}$, JOHN F. SLACK ${ }^{1,4}$

${ }^{1}$ Dept. of Earth Sciences, Memorial University of Newfoundland, Canada (*gabriel.sindol@mun.ca)

${ }^{2}$ Geological Survey of Newfoundland and Labrador, Canada ${ }^{3}$ Dept. of Geosciences, University of Tübingen, Germany ${ }^{4}$ U.S. Geological Survey, USA

A temporary resurgence of massive iron formation (IF) deposition at ca. $1.88 \mathrm{Ga}$ is an important junction in Earth's post-Great Oxidation Event history [1,2]. Occurrences of IF deposited at this time exhibit both small negative to large positive $\mathrm{Ce}$ anomalies, sub- and super-chondritic $\mathrm{Y} / \mathrm{Ho}$ ratios, and variably sloped shale-normalized REE $+\mathrm{Y}$ patterns. Collectively, these features have been interpreted as evidence for $\mathrm{Fe} / \mathrm{Mn}$-(oxyhydr)oxide-driven element cycling across a redox-stratified ocean [3]. However, few studies of ca. 1.88 Ga IF have integrated REE+Y data with a full suite of other redox-sensitive elements (i.e., $\mathrm{Cr}, \mathrm{Mo}, \mathrm{U}, \mathrm{V}, \mathrm{W}$ ) to further constrain the ocean-atmosphere redox architecture.

Here we present bulk-rock chemostratigraphic variations in REE $+Y$ and redox-sensitive elements in the ca. $1.88 \mathrm{Ga}$ Sokoman IF, Labrador Trough, Canada from two localities: Sheps Lake and Lac Ritchie. Similar to other coeval granular IF occurrences, the Sokoman IF shows: (1) negligible overprinting of REE $+\mathrm{Y}$ chemistry by insoluble element-rich detrital particles (ultra-low Al, Ti, Nb, Zr, etc.); (2) pervasively terrestrial over hydrothermal sources of soluble REE $+\mathrm{Y}$ (minimal $\mathrm{Eu}$ anomalies and positive La-Gd-Y anomalies); and (3) support for Fe/Mn-redox-stratified basin conditions with $\mathrm{Fe}-\mathrm{Mn}$-(oxyhydr)oxide shuttles resulting in both positive and negative $\mathrm{Ce}$ anomalies. Enrichment factors (EFs) of Cr, Mo, U, V, and $\mathrm{W}$ are generally low, consistent with their muted delivery under a low- $\mathrm{O}_{2}$ post-GOE atmosphere [4]. Nevertheless, there is variable coupling between EFs that appears to signify either shifting redox conditions, variable proxy sensitivity under low- $\mathrm{O}_{2}$ conditions, or minor element-specific detrital contamination. These results will be interpreted in the context of available data from other contemporaneous IF and deep-water equivalents to establish a more global perspective on oceanatmosphere redox at ca. $1.88 \mathrm{Ga}$.

[1] Bekker et al. (2010) Econ. Geol. 105, 467-508; [2]

Konhauser et al. (2017) Earth-Sci Rev. 172:140-177; [3]

Planavsky et al. (2010) GCA 74, 6387-6405; [4] Partin et al.

(2013) Chem. Geol. 362: 82-90 